\title{
PENEGAKKAN HUKUM TERHADAP PENIPUAN MELALUI MEDIA ELEKTRONIK
}

\author{
I Gusti Made Jaya Kesuma, Ida Ayu Putu Widiati, I Nyoman Gede Sugiartha \\ Fakultas Hukum Universitas Warmadewa, Denpasar-Bali, Indonesia
}

\begin{abstract}
Abstrak
Penipuan melalui media elektronik tengah marak terjadi di Indonesia pada era globalisasi ini. Hal tersebut menarik perhatian untuk meneliti tentang Penegakkan Hukum Terhadap Penipuan Melalui Media Elektronik. Penelitian ini bertujuan untuk mengetahui penegakkan hukum terhadap tindak pidana penipuan melalui media elektronik, dan untuk mengetahui faktor-faktor terjadinya tindak pidana penipuan melalui media elektronik. Penyajian ini menggunakan metode penelitian Normatif. Secara umum, tindak pidana penipuan di Indonesia diatur dalam pasal 378 KUHP, sedangkan tindak pidana penipuan dengan menyebarkan berita bohong yang merugikan konsumen dalam transaksi elektronik melalui media online atau elektronik diatur dalam pasal 28 Ayat (1) Undang-Undang ITE. Penyebaran berita bohong ini disamakan dengan tindak penipuan pada dunia nyata sebagaimana diatur pada pasal 378 KUHP. Penerapan sanksi pidana terhadap penipuan melalui media elektronik dapat dikenakkan pasal yang berlapis terhadap suatu tindak pidana yang memenuhi unsur-unsur tindak pidana penipuan sebagaimana diatur dalam pasal 378 KUHP dan memenuhi unsur-unsur tindak pidana pasal 28 ayat (1) Undang-Undang ITE.
\end{abstract}

Kata Kunci: Penipuan; Media elektronik; Penegakkan hukum

\begin{abstract}
Fraud through electronic media is rife in Indonesia in this era of globalization. This has attracted attention to research on Law Enforcement Against Fraud Through Electronic Media. This study aims to determine law enforcement against fraud through electronic media, and to determine the factors in the occurrence of fraud through electronic media. This presentation uses the Normative research method. In general, the criminal act of fraud in Indonesia is regulated in Article 378 of the Criminal Code, while the crime of fraud by spreading false news that harms consumers in electronic transactions through online or electronic media is regulated in Article 28 Paragraph (1) of the ITE Law. The spread of fake news is equated with fraud in the real world as regulated in Article 378 of the Criminal Code. The application of criminal sanctions against fraud through electronic media can be subject to multi-layered articles against a criminal act that fulfills the elements of a criminal act of fraud as stipulated in article 378 of the Criminal Code and fulfills the elements of a criminal act of article 28 paragraph (1) of the ITE Law.
\end{abstract}

Keywords: Fraud; Electronic media; Law enforcement

\section{PENDAHULUAN}

Indonesia adalah negara yang berlandaskan hukum (rechstaat), tidak berlandaskan dengan kekuasaan belaka (machstaat). Dengan memprioritaskan hukum diatas segala aktivitas dalam bernegara, salah satu upaya ialah dengan mengamalkan kemajuan dalam bidang hukum serta menciptakan suatu keadilan, kejelasan hukum, ketertiban, serta masyarakat yang mengerti dan patuh akan hukum. Penegakkan hukum haruslah sesuai dengan aturan-aturan yang berlaku serta berlandaskan pada ideologi Pancasila dan UUD NKRI tahun 1945 (Indonesia, 2014; Kurnia, 2016).

Kemajuan teknologi serta komunikasi yang memudahkan masyarakat dalam menyerap dan membagikan sebuah informasi kepada individu maupun publik. Bertepatan dengan kemajuan teknologi dan informasi publik pun dibuat untuk mengikuti segala perkembangan yang sedang terjadi. Dalam berkomunikasi dan bersosialisasi sangat diperlukannya kemajuan teknologi dan informasi, karena adanya hal tersebut maka memudahkan publik dalam segala hal yakni, berkomunikasi dengan cara baru, berjualan dengan cara baru, dan berbisnis tanpa adanya batasan waktu dan tempat. 
Hal ini membuka mata publik dengan adanya dunia baru yang perkembangannya yang sangat pesat. Internet ialah salah satu metode yang sangat sering digunakan dalam hal tersebut karena internet ialah salah satu perkembangan teknologi yang telah merubah dunia dari tahun ke tahun.

Penipuan ialah kejahatan yang paling sering terjadi dalam media elektronik, dimana kejahatan ini menawarkan berbagai macam hal terdiri dari transaksi bisnis, jual beli barang atau jasa dengan menerapkan harga yang tidak masuk akal atau dibawah normal. Akan tetapi hal ini tidak mudah dihindari karena transaksi ini sudah menjadi tren, maka dari itu tren ini membuka celah bagi oknum nakal, yang dimana para oknum ini berani melanggar aturan yang berlaku demi menguntungkan dan memperkaya dirinya sendiri ataupun orang lain. Bisnis secara online mempermudah para pelaku penipuan dalam melakukan aksinya (Chazawi, 2015). Penegakkan hukum yang belum tegas dan jelas kebenarannya menjadi pemicu pelaku penipuan dalam melakukan tindak pidana penipuan melalui media elektronik ini. Relevansi masalah dengan penelitian terdahulu oleh (Rahmanto, 2019; Ratnasari, 2015) menyebutkan bahwa dalam Undang-Undang ITE NO. 11 tahun 2008 serta diatur dalam KUHP Pidana pasal 378 tentang penipuan, sehingga dalam KUHP pidana telah diatur pula proses penanganan cybercime dimulai dari penyelidikan hingga putusan pengadilan.

Berdasarkan uraian diatas, dapat disimpulkan bahwa tindak kejahatan akan selalu ada karena pesatnya perkembangan teknologi dan cara berkomunikasi yang dimana kejahatan yang semakin canggih dan maju pula. Dibuktikan dengan dengan media yang digunakannya maka kejahatan akan memiliki banyak cara untuk melakukannya. Oleh sebab itu, tindak pidana penipuan yang menggunakan media elektronik ini memerlukan pemahaman/ pengertian yang lebih spesifik lagi serta peraturan apa saja yang digunakan dalam upaya menindaklanjuti aksi kejahatan tersebut oleh aparat penegak hukum serta upaya penanggulangannya.

Berdasarkan latar belakang yang telah diuraikan, maka peneliti membuat rumusan masalah yaitu : bagaimana aturan hukum tentang tindak pidana penipuan melalui media elektronik serta bagaimana penegakkan Hukum terhadap pelaku tindak pidana penipuan melalui media elektronik. Adapun tujuan dari penelitian ini ialah untuk mengetahui aturan hukum terhadap tindak pidana penipuan melalui media elektronik dan untuk mengetahui penegakkan hukum terhadap pelaku tindak pidana penipuan melalui media elektronik.

\section{METODE PENELITIAN}

Sebagaimana yang telah diuraikan diatas, maka metode penulisan yang digunakan dalam penelitian ini adalah dengan metode penelitian normatif yaitu dengan cara meneliti bahan pustaka hukum yang ada. Sumber bahan hukum yang dipergunakan bersumber dari penelitian kepustakaan berupa: Sumber bahan hukum primer berdasarkan KUHP dan UU No 11 Tahun 2008 tentang Informasi dan Transaksi Elektronik. Sumber bahan hukum sekunder diperoleh dari buku-buku, thesis, jurnal dan dokumen-dokumen yang dapat mendukung dari penelitian ini.

\section{HASIL DAN PEMBAHASAN}

\section{Aturan Hukum Tindak Pidana Penipuan Melalui Media Elektronik}

Penipuan memiliki kata dasar yaitu tipu yaitu perbuatan/ tindakan serta perkataan yang tidak benar/ jujur dengan maksud menjerumuskan, mengelabuhi atau mencari keuntungan. Sedangkan penipuan ialah prosedur, cara, langkah dalam menipu. Tindakan penipuan bisa disebut demikian karena seorang/ individu telah melakukan tindakan yang tidak terpuji dimana tindakan itu ialah menyebarkan atau mengatakan hal yang tidak benar berdasarkan suatu berita, kejadian, pesan, dan hal lainnya dengan tujuan tertentu demi menguntungkan satu pihak. Tindakan-tindakan yang bersifat mengelabui yang dilakukan seseorang untuk memberikan pandangan bahwa hal yang disampaikan atau disebarkan ini benar dan sesuai dengan fakta yang ada, tindakan penipuan ini bertujuan untuk mendapatkan kepercayaan orang lain atau masyarakat dan kemudian merugikan orang dan masyarakat tersebut. Di masyarakat tindak penipuan ini sangatlah sering terjadi karena pelaku memiliki tuntutan untuk memenuhi kebutuhannya sendiri maka segala cara akan dihalalkan termasuk menipu dengan tujuan untuk memenuhi kebutuhan sendiri dan mencari untung.

Tindak pidana penipuan seringkali terjadi di Indonesia yang disebabkan oleh beberapa faktor-faktor pendukung, seperti kemajuan teknologi yang membuka peluang bagi pelaku dalam melancarkan aksinya, terbelit utang, keadaan ekonomi dan lain sebagainya ialah alasan untuk memaksa seseorang melakukan penipuan. Seseorang yang melakukan tindak penipuan ini selalu 
termotivasi untuk melakukan tindak ini secara terus menerus dan berulang dikarenakan sang pelaku termotivasi untuk cepat kaya dan menganggap orang lain bodoh karena dirinya menganggap orang lain mudah untuk di bodohi atau ditipu. Pasal 378 KUHP menetapkan kejahatan penipuan dalam bentuk umum, serta dalam 20 pasal yang merumusakan berbagai bentuk penipuan terhadap harta benda yang masing-masing pasal mempunyai nama nama khusus yang tercantum dalam BAB XXV Buku II KUHP. Menguntungkan diri sendiri, menimbulkan kerugian pada orang lain, memperdaya orang lain untuk memberikan atau melakukan sesuatu dengan mempergunakan usaha-usaha penipuan dengan melawan aturan hukum yang berlaku seperti yang disebutkan secara liniatif dalam Pasal 378 KUHP ialah sifat dari tindak pidana penipuan itu sendiri. Pemenuhan kebutuhan atau keuntungan yang mengakibatkan seseorang melakukan penipuan maka dari itu tindak pidana penipuan sangatlah sering terjadi di lingkungan masyarakat.

Transaksi Elektronik ialah suatu perbuatan hukum dimana terjadinya suatu perjanjian antara penjual dan pembeli yang dilakukan dengan menggunakan media seperti computer, gadget, jaringan internet atau media eletronik lainnya seperti yang berdasarkan UU ITE. Ikatan hukum atau hubungan hukum yang dilakukan secara elektronik dimana adanya aktivitas jual beli didalamnya dengan menggabungkan jaringan dari media berbasis elektronik seperti komputer dan gadget dengan sistem komunikasi berbasis jaringan yaitu internet merupakan definisi dari transaksi elektronik tersebut. Kontrak dagang elektronik, transaksi dagang elektronik, dan kontrak web ialah, istilah lain yang sering digunakan dalam transaksi elektronik (e-commerce). Sehingga transaksi elektronik merupakan transaksi perdagangan antara penjual dan pembeli dengan memanfaatkan elektronik sebagai medianya dan internet sebagai jaringan penghubung antara media yang digunakan, sehingga proses pemesanan barang, pembayaran atas transaksi yang berlangsung sampai dengan pengiriman barang dikomunikasikan melalui media elektronik yang tersambung dengan internet (Massudilawe, 2008).

Penipuan dalam transaksi elektronik atau yang sering disebut juga dengan penipuan online yaitu kejahatan penipuan yang mengacu kepada aktivitas yang menggunakan komputer, gadget, dan segala hal yang menggunakan jaringan internet. Transaksi elektronik sendiri memiliki sifat-sifat atau karakternya masing-masing antara lain, yaitu :

1. Transaksi tanpa batas, dimana suatu bisnis online yang memiliki konsumen dan berkembang di berbagai negara yang memiliki modal yang sangat besar tanpa adanya batasan apapun.

2. Transaksi tanpa nama (anonim), yakni transaksi tanpa diperlukannya tatap muka, nama identitas atau tanda pengenal lainnya antara penjual dan pembeli.

3. Barang/produk digital dan non digital, yakni produk yang dijual ialah produk yang bersifat digital sepeti software yang dapat di download melalui internet dan non digital seperti barang elektronik dan kebutuhan keseharian seperti pakaian, kendaraan, dan lain lain.

4. Produk/ barang yang tidak berwujud, yaitu produk yang tidak memiliki wujud seperti berkas file, software, atau ide gagasan-gagasan yang dijual di internet.

Skema dari penipuan yang marak terjadi dalam transaksi elektronik sering terjadi dalam situs internet, ruang obrolan, iklan, dan email, yang dimana para pelaku memiliki peran dalam menawarkan produk/ barang kepada calon korban dimana produk/ barang tersebut sesungguhnya tidak pernah ada, berkomunikasi dengan adanya sifat menjerumuskan korban hingga menimbulkan kerugian dengan mengambil atau memindahkan dana korban, aset, atau barang lainnya tanpa sepengetahuan korban ke dalam penguasaan pelaku. Makna di atas, mengartikan penipuan melalui media elektronik yang terhubung ke jaringan internet memiliki pengertian yang hampir sama dengan penipuan biasa namun penipuan dalam transaksi eletronik ini menggunakan salah satu atau lebih komponen media dan komponen yang ada dalam internet seperti situs, ruang obrolan dan email (Budhijanto, 2017). Undang-undang Nomor 11 Tahun 2008 tentang Informasi dan Transaksi Elektronik UndangUndang ITE belum mengatur secara khusus tentang tindak penipuan melalui media eletronik maka pasal yang secara khusus yang bisa digunakan ialah pasal 378 KUHP dimana bisa disimpulkan bahwa siapapun dengan maksud menguntungkan diri sendiri atau pihak lain dengan melawan hukum, dan juga mejerumuskan orang lain untuk menyerahkan segala aset yang dimilikinya, dan menghilangkan piutang akan dipidana penjara paling lama 4 tahun.

Walaupun UU ITE belum secara khusus mengatur tentang penipuan yang dilakukan di media elektronik, namun ada timbulnya kerugian konsumen dalam bertransaksi di media eletronik 
seperti yang disimpulkan dari pasal 28 ayat 1 UU ITE dimana setiap orang yang menyebarkan berita yang tidak valid dan menjerumuskan orang lain pada kerugian. Maka pelaku yang melanggar aturan pasal 28 ayat 1 UU ITE dapat diancam pidana seperti yang ada di pasal 45A ayat 1 UU No 19 Tahun 2016 yaitu, pihak yang dengan sengaja menyebarkan berita yang tidak valid seperti yang dimaksud dalam pasal 28 ayat 1 UU ITE dapat dipidana penjara paling lama 6 tahun dan denda paling banyak 1 miliar rupiah. Bisa disimpulkan bahwa pasal 378 KUHP dan Pasal 28 ayat 1 UU ITE mengatur hal yang berbeda, yakni, pasal 378 KUHP tentang penipuan dan pasal 28 ayat 1 UU ITE mengatur tentang berita tidak valid/ bohong yang mengakibatkan kerugian pada konsumen dalam bertransaksi di dalam media elektronik.

Terpaut dengan rumusan Pasal 28 ayat 1 UU ITE yang menggunakan kalimat menyebarkan berita yang tidak valid/ bohong, yang juga sebenarnya terdapat kemiripan dengan ketentuan pada pasal 390 KUHP, walaupun dengan rumusan yang agak sedikit berbeda bisa disimpulkan bahwa pihak yang bertujuan untuk menguntungkan diri sendiri atau pihak lain dengan melawan hukum yang berlaku, dengan menyiarkan berita bohong, serta menyebabkan harga barang dan jasa menjadi tidak jelas maka akan dipenjara paling lama dua tahun delapan bulan. Dalam hal tersebut kalimat menyiarkan kabar bohong dan juga kerugian yang ditimbulkan lebih diatur secara spesifik. Jika dibandingkan aturan tersebut mempunyai kesamaan yaitu dapat menimbulkan kerugian terhadap konsumen. Namun, rumusan Pasal 28 ayat 1 UU ITE tidak mensyaratkan adanya unsur menguntungkan diri sendiri atau pihak lain sebagaimana diatur dalam pasal 378 KUHP tentang penipuan. Sesuai dengan adanya unsur-unsur yang sudah terpenuhi dari aturan Pasal 28 ayat $1 \mathrm{UU}$ ITE dan Pasal 378 KUHP maka pihak penegak hukum dapat menjatuhi pasal berlapis kepada pelaku tindak pidana penipuan yang telah memenuhi syarat-syarat dari kedua pasal tersebut.

\section{Penegakkan Hukum terhadap Pelaku Tindak Pidana Penipuan melalui Media Elektronik}

Syarat pembebanan terpidana terhadap pelaku tindak pidana penipuan melalui media elektronik dapat ditinjau dari terpenuhinya seluruh unsur dan tujuan dari dilakukannya perbuatan tindak pidana tersebut berdasarkan pada kenyataan bahwa penipuan tersebut dilakukan dengan kesengajaan dan dalam keadaan sadar akan dikecam oleh Undang-undang yang berlaku. Berikut Unsur- unsur yang terdapat dalam Undang-undang yang dimaksud ialah sebagai berikut: Unsur-unsur yang terdapat dalam Pasal 28 ayat 1 UU ITE, unsur obyektif, yaitu perbuatan yang telah menyebarkan berita yang tidak valid dan menjerumuskan dan dari perbuatan ini telah menimbulkan kerugian bagi konsumen yang telah bertransaksi di media elektronik. Unsur subyektif, yaitu tindakan menyebarkan berita yang tidak valid dengan disengaja dan menjerumuskan yang menimbulkan kerugian bagi konsumen yang bertransaksi di media elektronik dan melawan hukum tanpa hak.

Unsur-unsur yang terdapat dalam pasal 378 KUHP yaitu, Unsur Obyektif, perbuatan menggerakkan yang bertujuan untuk menyerahkan segala harta benda kepada pelaku, memberi piutang (kepada korban) dan menghapuskan piutang (kepada pelaku). Unsur Subyektif, perbuatan yang menguntungkan diri sendiri dan pihak lain serta dengan melawan hukum yang ada.

Dengan terpenuhinya unsur tersebut maka diberlakukannya sanksi pidana dimana perbuatan yang harus dipertanggungjawabkan atas perbuatan yang dilakukan. Pemidanaan ialah bertujuan untuk mencegah timbulnya tindak pidana yang sama dengan menegakkan hukum yang berlaku maka harus diterapkan dengan baik dan jelas. Pembuktian pertanggungjawaban pidana terhadap pelaku yang telah melakukan tindak pidana jika telah memenuhi syarat yakni pelaku telah melakukan tindak pidana, pelaku telah cakap hukum atau dewasa menurut undang-undang dan dapat dimintai pertanggungjawaban dan mampu bertanggungjawab atas tindakan yang telah dilakukan serta pembuktian yang dibutuhkan setelah terpenuhinya seluruh unsur dari kesalahan pelaku maka dibutuhkan adanya barang bukti untuk menguatkan bukti dari tindak pidana yang telah dilakukan maka diperlukan minimal dua alat bukti sebagai alat untuk meyakinkan hakim terhadap kasus dari tindak pidana yang sedang ditangani.

Dalam memutuskan suatu pidana perbuatan yang dipertanggungjawabkan seseorang harus terdapat sifat yang melawan hukum. Pada saat ini UU ITE belum memuat secara khusus tentang delik penipuan, dan pasal 28 ayat 1 UU ITE saat ini masih bersifat umum dengan titik berat perbuatan penyebaran berita yang tidak valid dan menjerumuskan serta menimbulkan kerugian pada konsumen yang bertransaksi melalui media elektronik (R, 1991). Dimana UU No 11 tahun 
2008 tentang informasi dan transaksi elektronik belum mengatur secara khusus tentang penipuan melalui media elektronik, selama ini tindak pidana penipuan hanya diatur dalam pasal 378 KUHP.

Walaupun Undang-undang ITE belum secara khusus mengatur mengenai tindak pidana penipuan melalui media elektronik dimana hal ini sangat diperlukan karena hal ini sangat sering terjadi dan telah menimbulkan banyak kerugian, dalam bertransaksi elektronik terdapat ketentuan pada pasal 28 ayat 1 UU ITE yakni pihak yang sengaja dan tanpa izin menyebarkan berita yang tidak valid atau diragukan kebenarannya dan menjerumuskan yang menimbulkan kerugian bagi konsumen dalam bertransaksi, maka tindak pidana ini dapat dijatuhi pidana penjara paling lama enam tahun dan denda paling banyak Rp. 1.000.000.000 (satu miliar rupiah), sesuai dengan pasal 45 ayat $2 \mathrm{UU}$ ITE.

Dengan demikian, diperlukan kejelian atau ketelitian para penegak hukum dalam menentukan penggunaan pasal-pasal yang memenuhi syarat akan terjadinya tindak pidana penipuan melalui media elektronik, pada praktiknya suatu tindak pidana yang telah memenuhi syarat-syarat akan terlibatnya tindak pidana penipuan yang secara khusus telah diatur dalam pasal 378 KUHP dan telah menyiarkan berita yang tidak valid/ bohong seperti yang sudah diatur dalam pasal 28 ayat 1 tahun UU ITE maka unsur-unsur tindak pidana penipuan melalui media elektronik telah terpenuhi, maka penegak hukum dapat menggunakan kedua pasal tersebut dan menjatuhi hukuman yang sesuai dengan pengamalan pasal-pasal tersebut.

\section{SIMPULAN DAN SARAN}

\section{Simpulan}

Untuk aturan hukum tindak pidana penipuan secara khusus saat ini hanya ada di pasal 378 KUHP, sedangkan menyebarluaskan berita yang tidak valid/ bohong hingga menyebabkan kerugian diatur kedalam pasal 28 ayat 1 UU ITE. Penyebaran berita bohong ini dengan penipuan yang ada di dunia nyata yang diatur dalam pasal 378 KUHP sehingga segala jenis transaksi elektronik yang merugikan salah satu pihak dapat dijadikan alat bukti yang sah dimata hukum. Kemudian penerapan sanksi pidana dapat dikenakan pasal berlapis jika unsur-unsur telah terpenuhi maka penegak hukum dapat menggunakan kedua pasal tersebut jika unsur-unsur tindak pidananya telah terpenuhi dan dapat menjatuhi hukuman pidana pada pelaku.

\section{Saran}

Pertama, perlu adanya sinkronisasi antara KUHP dengan UU ITE, aturan yang jelas dan lebih spesifik sangat diperlukan agar si pelaku benar-benar jera akan tindakan yang telah dilakukannya dan meminimalisir adanya kejahatan yang sama terulang kembali. Kedua, dibutuhkannya peran aktif para pihak yang berwenang untuk mengedukasi masyarakat tentang seluk beluk dan bahayanya penipuan melalui media elektronik ini sangat diperlukan, jika hal ini tidak terealisasikan maka akan banyak menimbulkan korban dan himbauan untuk masyarakat agar lebih berhati-hati dalam melakukan kegiatan transaksi melalui media elektronik agar kejadian ini tidak terjadi di kemudian hari.

\section{DAFTAR PUSTAKA}

Budhijanto, D. (2017). Revolusi Cyberlaw Indonesia Pembaruan dan Revisi Undang - undang Informasi dan Transaksi Elektronik 2016. PT Refika Aditama.

Chazawi, A. dan A. F. (2015). Penyerangan terhadap Hukum Pemanfaatan Teknologi Informasi dan Transaksi Elektronik. Media Nusa Creative.

Indonesia, M. K. R. (2014). Konsep Politik Hukum Indonesia Berlandaskan Pancasila dan UUD 1945.

Lembaga Negara Pengawal Konstitusi.

Kurnia, T. S. (2016). Sistem Hukum Indonesia Sebuah Pemahaman Awal. CV Mandar Maju. Massudilawe. (2008). Undang-Undang Informasi dan Transaksi Elektronik. Andi Publisher.

R, S. (1991). Kitab Undang - undang Hukum Pidana (KUHP) Serta Komentar - komentarnya Lengkap Pasal Demi Pasal. Politeia.

Rahmanto, T. Y. (2019). Penegakan Hukum terhadap Tindak Pidana Penipuan Berbasis Transaksi

Elektronik. Jurnal Penelitian Hukum De Jure, 1(1).

Ratnasari, P. (2015). Mekanisme Penegakan Hukum Terhadap Tindak Pidana Penipuan Melalui 
Jurnal Preferensi Hukum

Vol. 1, No. 2, 2020

Media Eletronik. Lex Administratum, 3(1). 